\title{
TEMPERATURE ALARM ON IRON-BASED BLYNK PLAYSTORE APPLICATION
}

\author{
Budi Prijo Sembodo*, Bagus Prima Mahardhika \\ Department of Electrical Engineering \\ University of PGRI Adi Buana Surabaya \\ *Corresponding email address: budi@unipasby.ac.id
}

\begin{abstract}
In this era, practical, effectiveness and safety in activities are the necessities and demands of life where almost all people make it a priority in their lives. Effectiveness in activities will be obtained by the availability of technology that supports it all. Various efforts have been made by humans to make neat clothes so as to create a clean impression and support various activities, an example of the results of human efforts that are widely used to overcome this is by using an iron. In addition, the majority of the equipment still requires manual operation. Apart from the practical side, but does not eliminate the safety side. So here the author is interested in conducting research on the practicality of use which is later expected to make the use of irons more efficient, practical and safe. The measured parameter is how the DS18B20 temperature sensor functions as a temperature response receiver that sends a signal to the temperature sensor module which will activate or deactivate the iron through a smartphone. The results of this study that the device is able to send a signal to the smartphone and if the temperature produced by the iron exceeds the maximum limit a warning sign will appear on the smartphone, and the user can operate the iron online and remotely using a smartphone. The speed of response received by the tool is also to be forwarded to the iron or smartphone is also in accordance with needs.
\end{abstract}

Keywords: iron, temperature sensor, DS18B20.

\section{INTRODUCTION}

As technological advances in life are demanded to be practical and modern. Technology in the world is getting faster and faster, and many electronic devices that were used manually operated now can be operated automatically. With the creation of sophisticated tools that can simplify human work. Quite a lot of research in the world, especially in the field of electronics [1]. These technological advances can also support activities in the household, laundry service companies, hotels and hospitals [2]. Almost every day many who use the iron to spruce up clothes. Because by tidying clothes using an iron can simplify the work of humans themselves and save time daily. It began with the development of the present age so that tidying up clothes was made easy too [3]. In the past, simple models of ironing can now be modified to become more sophisticated and more practical. The old-fashioned iron still uses the simple technology of using ON / OFF manually and cannot be operated remotely online [4]. Then it can damage the clothes if the temperature used is too hot and can cause a fire if it is turned on with a maximum temperature but not operated and not monitored [5]. It also resulted in daily electricity wastage. Based on the explanation of the above problems, researchers made the tool " TEMPERATURE ALARM IN IRON-BASED PLAYSTORE BLINK APPLICATIONS". So, a new system was made in the Iron to make it easier to use automatically remotely. To get maximum results, use the mini WEMOS D1 tool as a regulator of the program from Iron. Not only that, researchers also developed a tool by using an android smartphone as a remote control so that it could be monitored anywhere, so it was not bothered by human negligence. For sensors that are used on this Iron media using the Temperature Sensor DS18B20, then the way the sensor works sends the data to the WEMOS D1 mini then processed and displayed on the LCD or on a smartphone to find out the results.

\section{RESEARCH METHODS}

TEMPERATURE ALARM ON IRONBASED BLYNK PLAYSTORE APPLICATION products are designed for the use of irons that may be used in the future for equipment that uses other electrical energy such as televisions, mixers, 


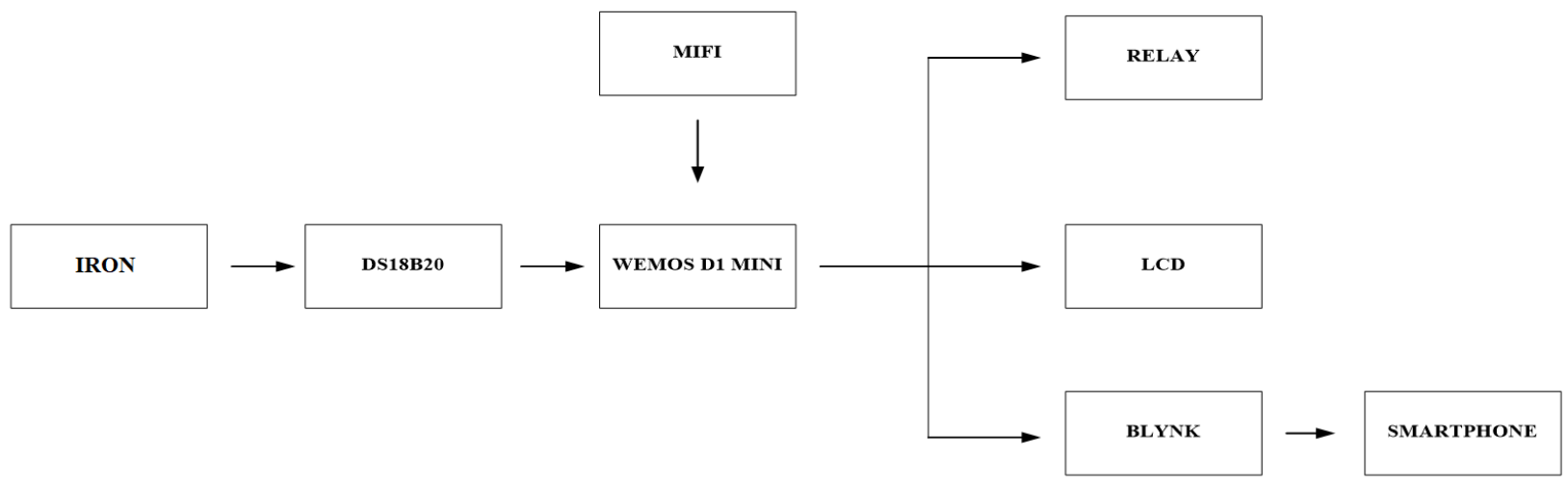

Figure 1. Block diagram of product design

washing machines, etc. This product is intentionally made to facilitate human work and keep abreast of electronic devices, instead of automatic switches by using a mobile phone as a device to turn on or give an on-off command to an online iron, using a Wifi connection. This product consists of hardware, namely Iron, Automatic Module consisting of Relay, IC Wemos D1 Mini + Relay, Blynk Application and Mobile Wifi. The application used is an application that will be installed on an android mobile phone, with menus and commands according to the program that will turn on or turn off electronic equipment commands.

How it works on the Figure 1 as follows, the iron sends a signal about the temperature scale to the DS18B20 temperature sensor [6], in this research temperature sensors DS18B20 is used because it has resolution to measure temperature every $0,0625{ }^{\circ} \mathrm{C}$ and have accuracy $\pm 0.5^{\circ} \mathrm{C}$ [7]. And then the DS18B20 temperature sensor forwards the signal to the Wemos D1 Mini, the internet network in this series is supported by MiFi (Mobile Wi-FI) functioned as a wireless link between the Wemos D1 Mini to the smartphone, relay the use of relays as automatic ON / OFF switches that can be operated with blynk applications, according to the data sent by the microcontroller. So, the tool can work well.

\section{RESULTS AND DISCUSSION}

\subsection{Software Research Results}

The software used is Blynk with version 2.27.1 by entering the library of each sensor which includes temperature sensor DS18B20 Functioning as a collection of codes that can run commands on each sensor that will be used in the main program.
The first command if the DS18B20 temperature sensor detects a temperature $\angle 90 \mathrm{oC}$ then the relay is connected and if the temperature is $>90 \mathrm{oC}$ the relay will be disconnected. The use of the 2channel relay program as an automatic switch operated by a temperature sensor and as a manual switch that can be operated by the blynk application on a smartphone. So that data can be displayed on the LCD and smartphone. With it displayed to a smartphone it can be monitored and operated anywhere. With notes Wemos D1 Mini and smartphone must be connected by the internet so that both can be operated. In testing this tool is supported by an internet connection using Mobile Wifi (Mifi) with the M3y Smartphone brand that has a $4 \mathrm{G}$ network with quality that is commonly used in the community.

\subsection{Implementation and testing of the main menu screen}

The results of the implementation of the main menu display design can be seen in Figure 2 showing the title of the application (thesis), on / off button, temperature gauge, graph of temperature change of the iron periodically and the exit button of the application. The testing phase on the main menu is by entering each control menu and usage instructions. The result is that each menu successfully leads to the intended screen according to the button name. Testing the application close / exit button when the button is touched will display a warning whether the user is sure to close the application or not. When "closed" is selected, the application is successfully closed. When selecting "cancel" then the user is still on the screen. 


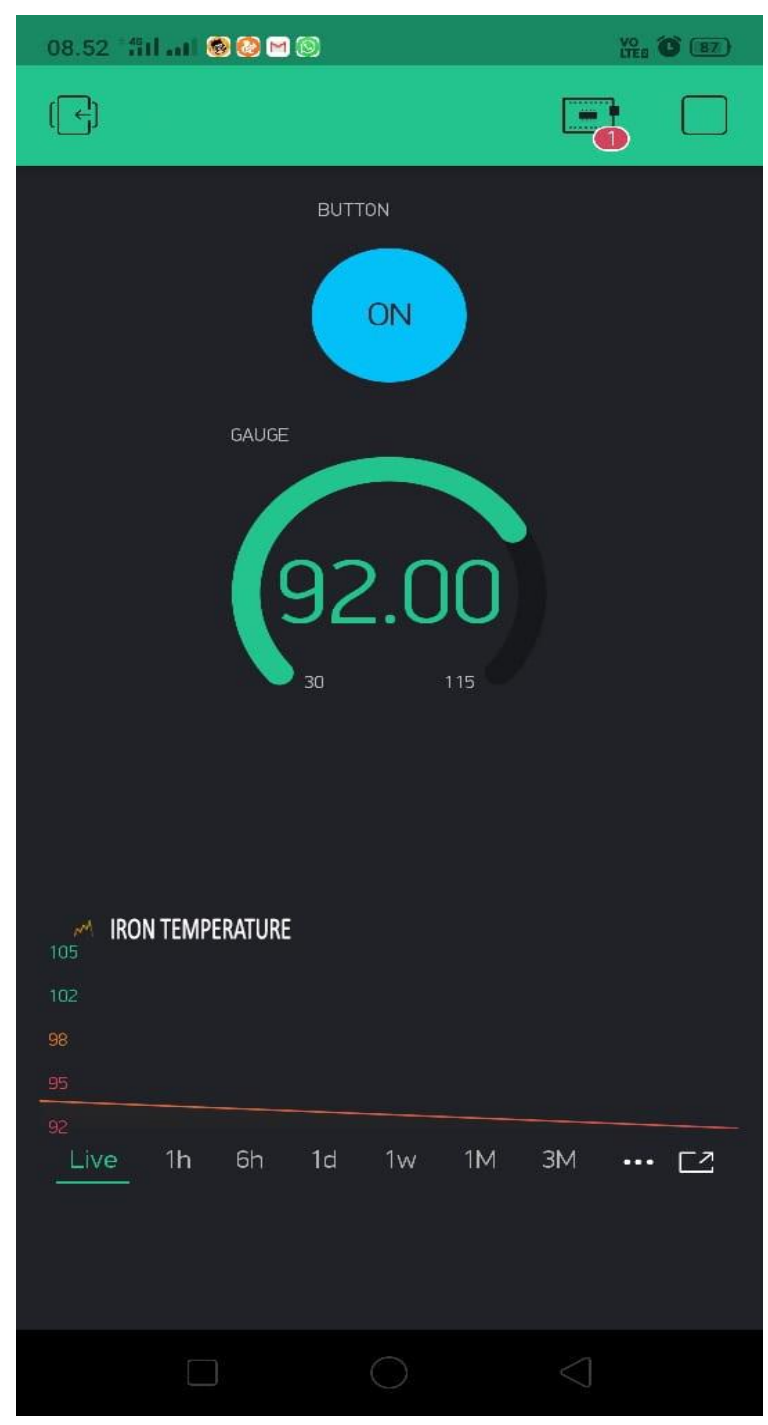

Figure 2. Main menu screen display

\subsection{Implementation and testing of the on/off switch screen}

The results of the implementation of the design of the on / off switch display can be seen in Figure 3 on the on / off switch screen displays the switch button, the bottom of the on / off button there is a gauge to regulate the temperature of the iron, Testing the on / off switch first tested the on / off button on application. Touch / press the on button, the green light indication on the toolbox lights up indicating the temperature of the iron is still below $100{ }^{\circ} \mathrm{C}$ successfully connected. Testing the function of the off button by touching the seven buttons off, the results display an off indication with a red light on the box indicating the data was successfully sent to the Mini D1 wemos and the command to turn off the power source has been successful.

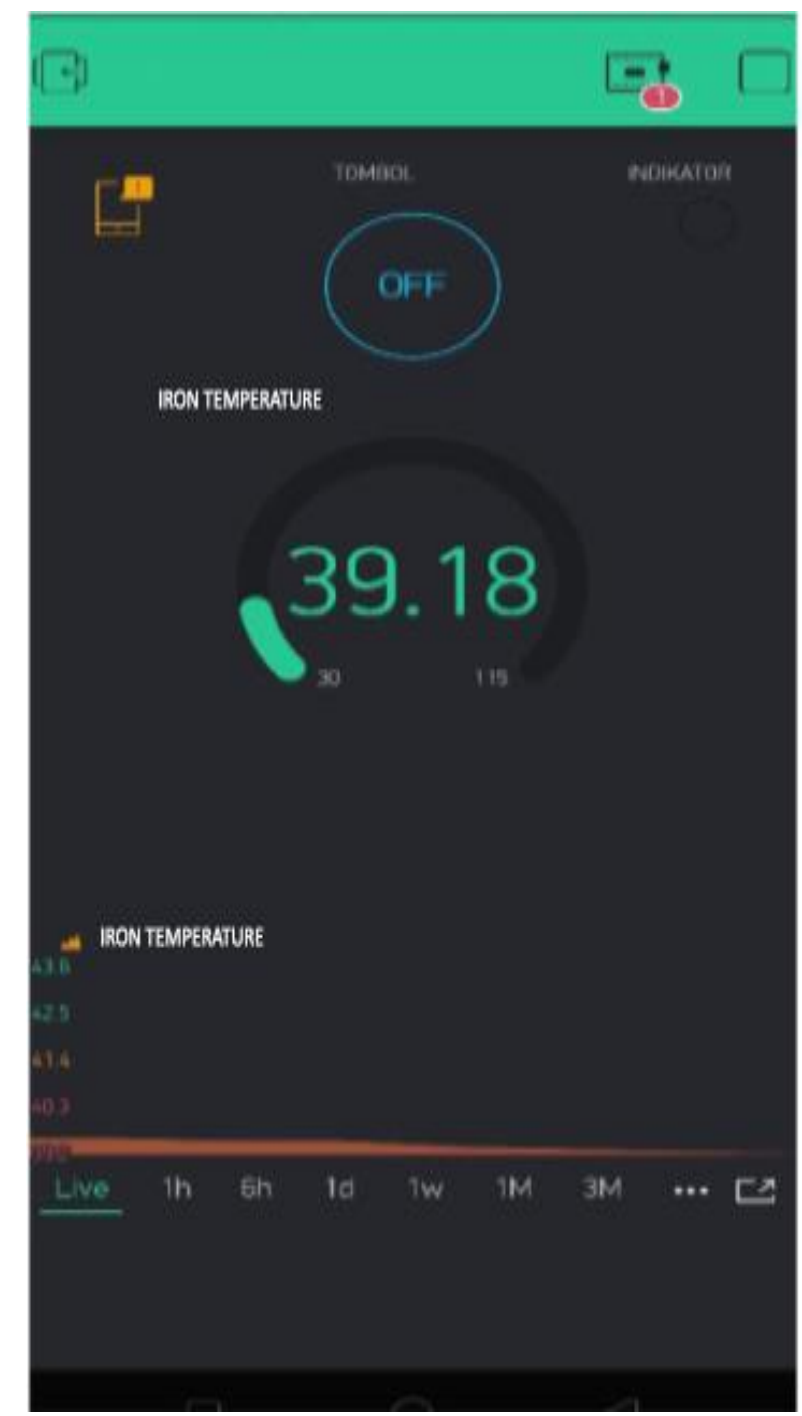

Figure 3. Implementation and testing of the on-screen switch

\subsection{Implementation and testing of notification marks}

The temperature signal obtained by the Ds18b20 temperature sensor inside the iron element will be forwarded to the Mini D1 Wemos which has got an internet connection from MIFI to be sent to the Smartphone via the Blynk application. Signals in the form of notifications will be received by blynk when the iron temperature exceeds $100{ }^{\circ} \mathrm{C}-116{ }^{\circ} \mathrm{C}$. The signal will be received once every 3 seconds if there is no command to turn off the power source and the temperature has not reached below $100{ }^{\circ} \mathrm{C}$. When the power source is turned off by Blynk, the temperature of the iron slowly drops and reaches a cold point. And the temperature notification will stop being received when the temperature is below $100{ }^{\circ} \mathrm{C}$. 


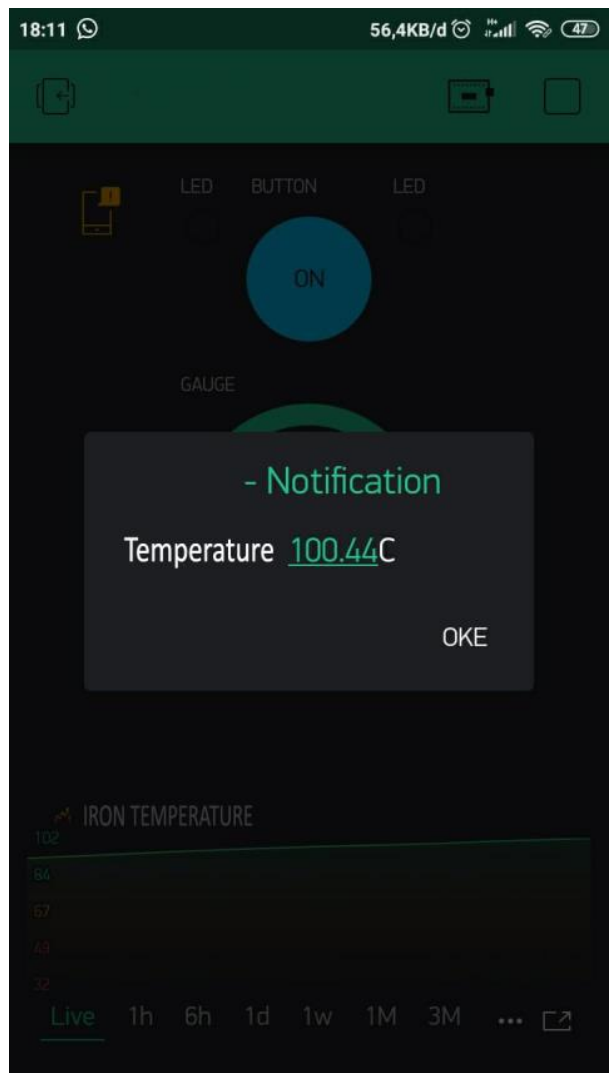

Figure 4. notification image on blynk on a smartphone

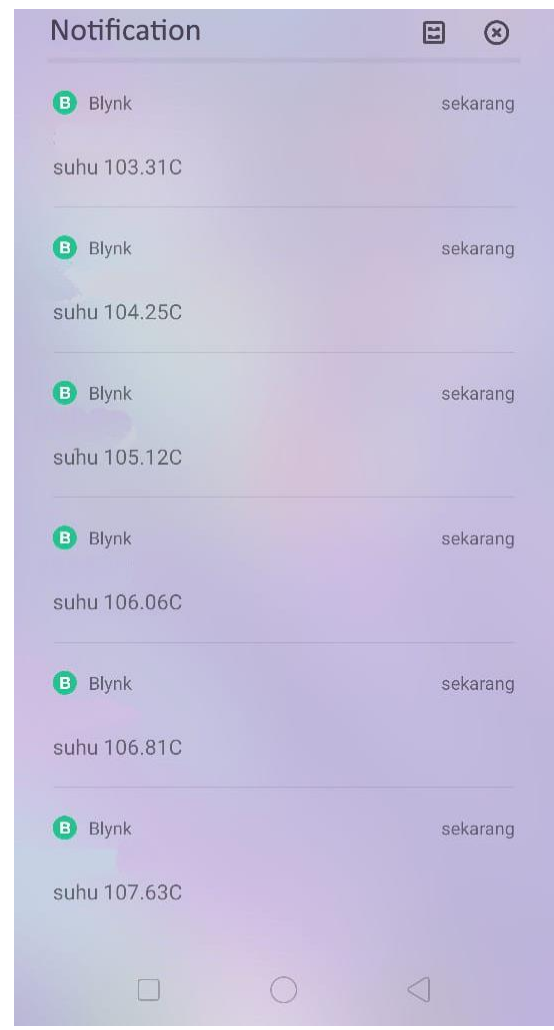

Figure 5. notification image on blynk on a smartphone

As in the Figure 5, it shows that the warning notification will be sent to the smartphone every 3 seconds until the temperature of the iron drops below $100{ }^{\circ} \mathrm{C}$ and the notification will stop to be received.

\section{CONCLUSION}

Based on the results of the implementation of the Making Temperature Alarm on Iron-Based Blynk Playstore Application tool, several conclusions can be made:

1. The application for making temperature alarms on irons on android smartphones has been successfully created using the Blynk playstore application. The Temperature Alarm Making application consists of an on / off switch and a warning sign on the Blynk application. Each control switch displays buttons like a real switch and an indication if the temperature on the iron exceeds the maximum limit. The user must turn on and connect the switch on the smartphone in the Blynk application to control. All types of control switches managed to control the temperature of the iron in accordance with their respective functions.

2. In the trial of a device that implements the distance and speed of response, it is found that the time needed for the device to respond to the temperature obtained from the iron to be forwarded to the smartphone. With the time obtained, it still shows a good response and not too slow, but also depends on the internet connection in the tool.

\section{ACKNOWLEDGMENT}

I thank to PGRI Adi Buana University Surabaya Faculty of Industrial Technology especially the Electrical Engineering study program, which has provided laboratory facilities.

\section{REFERENCE}

[1] A. Solih and J. Jamaaluddin, "Rancang Bangun Pengaman Panel Distribusi Tenaga Listrik Di Lippo Plaza Sidoarjo Dari Kebakaran Berbasis Arduino Nano," JEEE-U J. Electr. Electron. Eng.-UMSIDA, vol. 1, no. 2, Art. no. 2, Nov. 2017, doi: 10.21070/jeeeu.v1i2.1171.

[2] R. Aisuwarya, "Implementasi Sistem Kontrol Kestabilan Suhu Penghangat Nasi Menggunakan Metode Fuzzy Logic Dengan 
Pengujian Pada Varietas Beras Unggul

Sumatera Barat," J. Tek. Komput., vol. 4, no.

1, Art. no. 1, Jan. 2018, doi:

10.31294/jtk.v4i1.2764.

[3] A. R. Putra, E. Yudaningtyas, and G. D.

Nusantoro, "Sistem Pengendalian Suhu Pada

Tungku Bakar Menggunakan Kontrol Logika Fuzzy," J. Mhs. TEUB, vol. 1, no. 5, Art. no. 5, Jul. 2014, Accessed: Jul. 03, 2020.

[Online]. Available:

http://elektro.studentjournal.ub.ac.id/index.ph $\mathrm{p} /$ teub/article/view/143.

[4] S. Vashi, J. Ram, J. Modi, S. Verma, and C. Prakash, "Internet of Things (IoT): A vision, architectural elements, and security issues," Feb. 2017, pp. 492-496, doi: 10.1109/ISMAC.2017.8058399.

[5] A. S. Wibowo and E. Susanto, "Performance Improvement of Water Temperature Control using Anti-windup Proportional Integral Derivative," Lontar Komput. J. Ilm. Teknol. Inf., pp. 81-94, Sep. 2018, doi: 10.24843/LKJITI.2018.v09.i02.p03.

[6] M. Ristiawan and E. Ariyanto, "OTOMATISASI PENGATUR SUHU DAN WAKTU PADA PENYANGRAI KOPI ( ROASTER COFFEE ) BERBASIS ATMEGA 16 PADA TAMPILAN LCD ( LIQUID CRYSTAL DISPLAY )," Gema Teknol., vol. 19, no. 1, Art. no. 1, Oct. 2016, doi: 10.14710/gt.v19i1.21949.

[7] Sujiwa, Akbar, and Sagita Rochman. "Pengembangan Sistem Kontrol Serta Monitoring Suhu dan Volume Air Berbasis Web Pada Perangkat Desalinasi Air Laut." SNHRP (2019): 1-9. 